> Tips om medisinsk litteratur, andre bøker, filmer og elektroniske medier som bør anmeldes, sendes redaksjonen@tidsskriftet.no

\section{Terningkast «sex»}

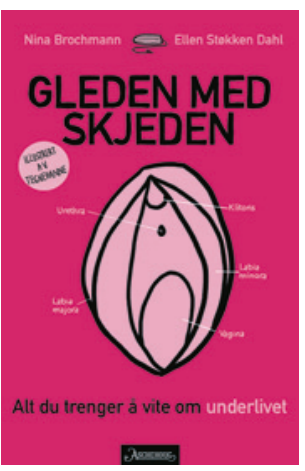

Nina Brochmann, Ellen Støkken Dahl Gleden med skjeden

Alt du trenger å vite om underlivet. 309 s, ill.

Oslo: Aschehoug, 2017. Pris NOK 349 ISBN 978-82-03-29579-9

Denne boken om kvinners underliv er intet mindre enn herlig å anmelde! I motsetning til Aftenpostens litteraturanmelder, tror jeg de færreste mister sexlyst eller underlivsglede av å lese denne.

Omslaget opplyser at den passer «for alle som er født med en vulva» og målgruppen er yngre kvinner. Jeg vil påstå at målgruppen inkluderer alle som ønsker å lære mer om kvinners underliv, uavhengig av alder eller kjønn. Jeg er ikke i tvil om at Gleden med skjeden har et stort internasjonalt potensial, og kjenner ikke til tilsvarende god og popularisert helseformidling om kvinners underliv. Jeg nøler ikke med å anbefale den som en nyttig bok også for medisinstudenter og helsepersonell generelt.

Forfatterne er medisinstudenter med erfaring fra Medisinerstudentenes seksualopplysning og som skribenter på bloggen Underlivet. Språket i Gleden med skjeden bærer preg av dette. Forfatterne viser stor evne til å kommunisere enkelt om helse, underliv og det eventuelt tabubelagte. De skriver entusiastisk og positivt om underlivets gleder. I tillegg legger de ikke skjul på underlivets mulige plager. Forhåpentligvis kan forfatternes praktiske råd forebygge de mange misforståelsene vi som jobber i fagfeltet opplever at unge kvinner har.

Boken er inndelt i fem hovedkapitler: Underlivet; Utflod, mensen og annet gørr; Sex; Prevensjon; Trøbbel i underlivet. Det siste kapittelet inkluderer nyttig informasjon om de vanlige underlivsplager unge kvinner kan oppleve. Prevensjonskapittelet er flott forenklet og popularisert, og illustrasjonen over typer midler er forbilledlig fremstilt. De enkle og ofte humoristiske illustrasjonene av Tegne-Hanne støtter godt opp om teksten.

Jeg har ett enkelt forslag til endring i neste utgave. Jeg synes ordet «digg» er i overkant ofte brukt i enkelte deler av boken, noe som antakeligvis reflekterer bloggspråket. Jeg representerer imidlertid en eldre lesergruppe enn målgruppen, slik at mitt behov for noe mer nyansert ordvalg i beskrivelsen av gleden med sex, kan være av forhistorisk karakter.

Forfatterne takker blant annet sine lærere på medisinstudiet ved Universitetet i Oslo. Som en av de mange lærerne de må ha møtt på sin vei, er jeg svært imponert over deres evne til å popularisere omfattende fagkunnskap. Jeg finner ingen viktige faglige misforståelser. Gleden med skjeden er rett og slett en fabelaktig god folkelig undervisningsbok om kvinners underliv og seksualitet. Forfatterne bidrar underveis med mange hverdagslige og sunne betraktninger, som bidrar til å dempe angst og til å øke gleden ved underlivet. Deres kloke råd kan eksemplifiseres med bokens avsluttende setning om at «Når alt kommer til alt, er kroppen bare en kropp, men den er verdifull fordi den er den eneste kroppen du kommer til å få̀.

Annetine Staff

Professor, Kvinnesykdommer, Universitetet i Oslo

Forskningsleder og overlege, Kvinneklinikken, Oslo universitetssykehus

\section{Overraskende interessant om turnusarbeid}

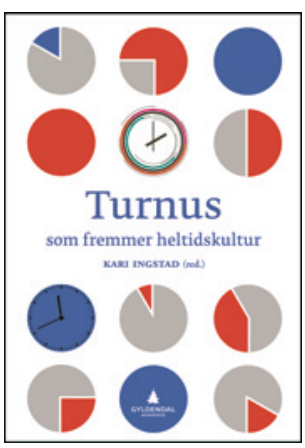

Kari Ingstad, red.

Turnus som fremmer heltidskultur

223 s, tab, ill. Oslo: Gyldendal Akademisk,

2016. Pris NOK 349

ISBN 978-82-05-49034-5

Forfatterne er arbeidslivsforskere som gransker forholdet mellom turnusarbeid og del-/heltidsarbeid i helse- og omsorgssektoren, med det uttalte mål å fremme heltidsarbeid. Målgruppen må derfor være ledere og tillitsvalgte $\mathrm{i}$ institusjoner med turnusarbeidere.

Turnus som fremmer heltidskultur omhandler først og fremst sykepleiere, vernepleiere, omsorgsarbeidere og pleieassistenter. Legegruppen nevnes svært kort, og kun som sammenligningsgrunnlag med de øvrige gruppene. Som kjent er leger i hovedsak fulltidsarbeidere, og som dagarbeidere med vakttjeneste er vi ikke turnusarbeidere $\mathrm{i}$ bokens forstand.

Boken er delt $i$ to deler med respektive seks og ni kapitler. Del 1 er bakgrunnsstoff, hvor det ses bakover i tid på den historiske utbredelsen av turnusarbeid, karrieremønstre og kjønnsroller. Den forklarer turnustekniske forhold som synes å ligge til hinder for heltidsstillinger, hvorfor disse har oppstått og hvorfor heltidskulturen er så vanskelig å oppnå. Turnusen er grunnsteinen i helsevesenets arbeidsliv, og kapitlene bør derfor utgjøre interessant lesning for de fleste som jobber i det. Spesielt kapitlet Bra arbeid for grepa damer er interessant, hvor konseptet «bra arbeid» kobles både til produktive arbeidsplasser og gode liv. Her ses turnus som et redskap som «kan optimaliseres slik at den bereder grunnen for bra arbeid».

Del 2 er den mer fremtidsrettede hoveddelen, og tar for seg ulike måter turnusarbeid kan organiseres på. Langvakter, vikarpool og forskjellige former for forhandlingsturnus er nøkkelord. Flere kapitler tilegnes detaljerte evalueringer av ulike turnusformer i omsorgsinstitusjoner, deriblant 3-3-modellen (3 dager med 12-timersarbeid fulgt av 3 dager fri i kontinuerlig, rullerende plan). Denne delen er betydelig mer tunglest, og fremstår langt mindre interessant for en tilfeldig leser enn for den som faktisk skal planlegge sine arbeidstageres arbeidstid.

Forfatterne trekker få konklusjoner, men understreker gjentatte ganger at de ansatte må involveres i endringsprosessene dersom de skal lykkes. Som de skriver: «God endringsledelse innebærer å kjenne organisasjonen man skal endre».

Overskriften gjenspeiles i at dette i utgangspunktet er tørre greier. Bokens første del klarer å fenge leseren på overraskende vis, med et innblikk i kollegers arbeidsform som setter vår egen i relieff. Samlet sett anbefales boken dog kun til de med spesiell interesse innenfor arbeidstidsplanlegging.

Mats Kleivane

Tillitsvalgt, Yngre legers forening 